\title{
Katharina Uhde, The Music of Joseph Joachim
}

(Woodbridge: Boydell \& Brewer, 2018. ISBN: 9781783272 846; 532 pp.)

Joseph Kerman wrote in 1983 that "a canon is an idea; a repertory is a program of action" and that "repertoires are determined by performers, canons by critics." While the musical canon and repertoire share substantial areas of overlap (Mozart, Beethoven, Tchaikovsky), the distinction between the two can be highlighted by pieces of music that are established in the canon but not in the repertoire and vice versa, for example, Schoenberg's Violin Concerto and Wieniawski's Violin Concerto no. 2 respectively. Kerman's words were not far from my mind as I read The Music of Joseph Joachim.

Joseph Joachim is well known in music history as a violinist, as the friend, collaborator and champion of Brahms, Schumann, Mendelssohn, Liszt and others, whose expertise and input, artistic outlook, and performing style had a significant impact on them and on the legacy of their music - his role in shaping Brahms's Violin Concerto and the anomalous "F. A. E." sonata and his contribution of cadenzas to numerous concertos being only the most famous examples of this.

Joachim is not well known as a composer. With the sole possible exception of his Hungarian Concerto, which has on occasion graced the concert stage and recordings, none of Joachim's music has been established in the canon or the repertoire. I can hardly think of a figure in nineteenth-century European music history whose identity and agency as a performer and composer were more polarized - central in one respect, marginal in the other. For such a celebrated musical 
figure, a Geigerkönig of unparalleled stature in Western classical music, his own compositional voice and output have remained in the shadows.

Katharina Uhde's new book is a welcome addition to the field for taking this larger-than-life performer's compositions as its subject. In some respects, it is surprising that such a book has not been published until 2018, more than a century following Joachim's death. While a number of biographies have appeared (from Fuller-Maitland $1905^{2}$ to Borchard $2005^{3}$ ) as well as several analytical essays on Joachim's music (Tovey's in the 1930s ${ }^{4}$ ), this is the first large-scale study of his complete compositional oeuvre.

At 532 pages, with 15 black and white, 214 line illustrations it is a substantial undertaking. In eleven chapters, the book covers no fewer than three violin concertos, two fantasies, three variation sets, five incidental pieces for violin and piano or violin and orchestra, a string quartet movement, five overtures, and two marches, spanning nearly half a century (1848 to 1896); for obvious reasons, many of these works feature a highly skilled solo violin part. Presented in chronological order, the book comprehensively charts his compositional development using Schumann's metaphor for Joachim's transformation from (virtuoso) chrysalis to (composer) butterfly. Uhde provides rich details of Joachim's various musical influences, personal and literary inspirations, his self-reflective stance on composition as an authentic expression of the composer's inner life, and identity issues he faced as a German-assimilated Hungarian Jew in the post-1848 period.

The author shows, for example, how Joachim's voice as a young composer developed after Mendelssohn died (Chapter 2), and how his New German School leanings in his first Violin Concerto are evidenced by his handling of form, of Lisztian motivic transformation, and of Lisztian virtuosity (Chapter 3). The author further argues that despite being seen as a New-German composer early in his career, he was actually much more tradition-bound, adhering to classical principles - as evidenced by his Hamlet Overture which, given its similarity to Beethoven's Coriolanus Overture, and in stark contrast to Liszt's own forward-looking Hamlet, fulfilled Schumann's belief that future music would continue rather than disrupt received compositional parameters (Chapter 4).

Turning now to what Uhde (following Joachim) calls his "psychological music," readers can glimpse the tremendous personal influence of the writer Gisela von Arnim, whom Joachim adored. It was on her name that he created a musical cipher (Gis-E-La or G sharp-E-A) that he used in a number of compositions, such as the Three Pieces op. 5 (Chapter 5). Joachim called her "O you soulful G sharp" (Gis-Seele), "leading tone to the passionate A major in my inner soul"

2. John Alexander Fuller-Maitland, Joseph Joachim (London: J. Lane, 1905) = Living Masters of Music, 6.

3. Beatrix Borchard, Stimme und Geige. Amalie und Joseph Joachim. Biographie und Interpretationsgeschichte (Wien: Böhlau, 2005)= Wiener Veröffentlichungen zur Musikgeschichte.

4. Donald Francis Tovey, Essays in Musical Analysis, vol 3: Concertos (Oxford: Oxford University Press, 1937). 
(in a letter of 1854). That he combined her cipher with his own motto (F-A-E or "für alle Ewigkeit" rather than "frei aber einsam"), meant that the pair formed a kind of musical union in the absence of one in real life - she eventually chose writer Hermann Grimm and married him in 1859. Indeed, Uhde interprets the dramatic conflict between D major and F sharp minor in Joachim's Demetrius Overture autobiographically, as perhaps an expression of Joachim's and Grimm's rivalry for Gisela's affections (Chapter 6). It was Gisela who characterized Joachim's music as bitter and dark in style, more often than not in minor keys, with brooding themes.

The interactions Joachim had as a composer with the canonical composers in his orbit make for fascinating reading. Schumann was fond of Joachim's Henry IV Overture, of which Brahms made a piano arrangement along with several other overtures (Chapter 7). The Variations on an Original Theme for viola and piano, op. 10, stands out because of the praise elicited from both sides of the aisle Liszt, on the one side, and on the other, Schumann, who said of the first variation "what a melody!" as well as Brahms and Grimm, who remarked on the unusual combination of learned counterpoint and "Gypsy" flair (Chapter 8). Joachim's relationship with Brahms was particularly close - they even exchanged counterpoint exercises (Chapter 5). Brahms praised his String Quartet movement but pointed out that modulations happened too hastily, which Joachim took under advisement in his revised version (Chapter 7). Brahms criticized parts of the Variations on Irish Elfenlied because the theme could not be grasped aurally but was only evident visually in the score (Chapter 8).

From these chapters, a multi-faceted portrait emerges of Joachim as a composer with complex motivations and anxieties (he confessed to his brother his terrible insecurity as a composer), as an artist surrounded by a stimulating circle of literary and musical friends, and as a person with a keen sense of humour years after an English concert program accidentally printed "Lieder by Joachim" as "Leider by Joachim", he still joked "Leider von mir" ("unfortunately by me"). The sheer amount of primary and secondary source research, including archival work, sketch study, reception study, biographical and epistolary literature review, and background contextual knowledge that goes into creating a historically nuanced portrait of this kind is vast, and for this alone the book is a remarkable achievement.

The book does, however, pose a number of problems in ways that turn out to be interrelated. For instance, some readers may object to an over-emphasis on formal analysis and descriptions of the harmonic and thematic construction of almost every piece, section by section, in tables and in prose. A great many pages are devoted to this, to the detriment of considering other aspects of musical composition, such as his approach to orchestration or writing for piano. How did Joachim handle writing for woodwind instruments, for example? Certainly, orchestral color per se was something of more inherent interest to the New German 
School than the other faction but still the question remains, especially in view of the fact that he was actively engaged as a soloist with a wide range of orchestras. What did he learn about orchestral voicing from having this immersive experience? How did he learn to compose idiomatically for piano and what was the basis for his developing this skill? Finally, on a more esoteric level, did he conceive of his scores as representations of fixed works for eternity or as attempts to transcribe live musical events?

The majority of the music examples throughout the book oddly lack tempo markings, which simultaneously undermines the reader's ability to imagine how the music goes and emphasizes the visuals of the notes as abstract structures; this is especially noticeable in examples 6.10 and 6.11, which present similar rhythmic figures side by side for comparison, but only one with a tempo marking and time signature. Not only does the author seem to assume that the reader will share her de facto prioritization of score analysis, perhaps more importantly, formalism assumes that structure is fundamental to the meaning of a piece and derives its authority from analytical methods predicated on nineteenth-century Austro-Germanic ideals of organicism and genius. Evaluating Joachim's music on such terms is implicitly value-laden because such ideals were normative and hegemonic, and drove canon-formation. The implication is that the structural originality found in Joachim's music (his penchant for building phrases by means of rhythmic augmentation, for example) legitimates its artistic worth. It is not difficult to see why the author has adopted this strategy - Joachim himself aspired to such legitimation - but it does leave an awkward question hanging, namely, if his music was so masterful, then why has it been forgotten? In this regard, it is noteworthy that only the Hebrew Melodys [sic] is highlighted as a work that "has so far not received the attention that it deserves", although arguably the entire book can be taken as an implicit endorsement that all of Joachim's music ought to be better known.

To be fair, Uhde does question why the Hungarian Concerto "has not secured its place in the canon" although perhaps it would be more a propos to question why the Hungarian Concerto has not secured its place in the repertoire. Although historical contextualization by comparison to the compositional practice of other virtuoso violinists such as Paganini and Ernst would be useful for a certain readership, they are mentioned only in passing and with little or no reference to their performing styles. ${ }^{5}$ What was Joachim's self-conception as a virtuoso violinist composer in relation to the example set by his predecessors (mainstays of the virtuoso repertoire if not the canon to this day)? Ferdinand David makes a brief

\footnotetext{
5. For historical accounts of virtuoso violin performing styles, see Maiko Kawabata, Paganini, the "Demonic" Virtuoso (Woodbridge, Suffolk and Rochester, NY: Boydell \& Brewer/ University of Rochester Press, 2013) and Exploring Virtuosities: Heinrich Wilhelm Ernst, Nineteenth-Century Musical Practices and Beyond, Christine Hoppe, Melanie von Goldbeck and Maiko Kawabata (eds.) (Hildesheim: Olms-Verlag, 2018) =Göttingen Studies in Musicology (Göttinger Studien zur Musikwissenschaft).
} 
cameo appearance as the first performer of Joachim's Variations on an Original Theme (op. 10) but nothing is made of their relationship, camaraderie or stylistic affinity as fellow artists. And although some women violinists such as Betty Schwabe and Bianca Panteo float into the narrative as performers of Joachim's music, no consideration is given to what role (if any) they played in shaping his conception of writing for violin. (Nor, for that matter, do Clara or Fanny figure alongside Robert and Felix in this book.)

Most peculiarly of all, the intriguing fact that Joachim dedicated his Variations for Violin with Orchestral Accompaniment to his contemporary and erstwhile rival, Pablo de Sarasate, is stated but not explained: "Joachim seems to have designed his composition for Sarasate", the author claims, without supporting evidence. The triple and quadruple stops discussed under "virtuoso skills" were hardly Sarasate-specific, having been commonly utilized by earlier virtuoso violinists such as Paganini. Nor does the author mention that Sarasate had dedicated his Spanish Dances op. 21 to Joachim in 1878.

Indeed, the widely exoticized Spaniard represents a significant point of comparison to Joachim as a fellow "othered" virtuoso violinist in the late nineteenth century - one who composed a showpiece on Hungarian melodies (Zigeunerweisen) that has become a perennial favorite of the salon and the concert hall, no less. Contemporary critics frequently contrasted their playing styles; for example, when both violinists performed the Beethoven Violin Concerto in London, in the 1880s, enabling a side-by-side comparison, critics praised Joachim for his masculinity and loftiness while remarking on Sarasate's polish and out-of-place virtuoso cadenza. ${ }^{6}$ Leopold Auer, who studied with Joachim, contrasted his teacher's "classicism" with Sarasate's "elegant perfection." The clashing performance aesthetics of the two violinists was even captured in a caricature depicting them fighting a "duel" wielding their bows like swords (see Facsimile 1). ${ }^{8}$ This oppositional imagery is hard to reconcile with Joachim's dedication of the Variations to Sarasate. What did the two make of each other? To my knowledge, there is no evidence that Sarasate knew of the Variations' existence, let alone actually performed the piece - although we know he made a regular practice of performing the works of others. And why would a composer aspiring to acceptance by his German peers produce such an unabashedly virtuoso showpiece as late as 1879 ? Moreover, the suggestion that the idea for the Variations was sparked by the experience of working on Brahms's Violin Concerto the previous year is a significant detail that deserves fleshing out.

6. For example, N. N., "Mr. Sarasate's concerts," The Musical Times 557/30 (1 July 1889), 408.

7. Boris Schwarz, Great Masters of the Violin: from Corelli and Vivaldi to Stern, Zukerman and Perlman (London: Hale, 1983), 419.

8. Reprinted in Karl Storck, Musik und Musiker in Karikatur und Satire: eine Kulturgeschichte der Musik aus dem Zerrspiegel (Oldenburg: G. Stalling, 1910), 128. 
FACsimile 1 "Der Spanier hat schon blank gezogen. Der Ungar wehrt sich mit dem Bogen" ("The Spaniard has already unsheathed. The Hungarian defends himself with the bow"). Anonymous caricature

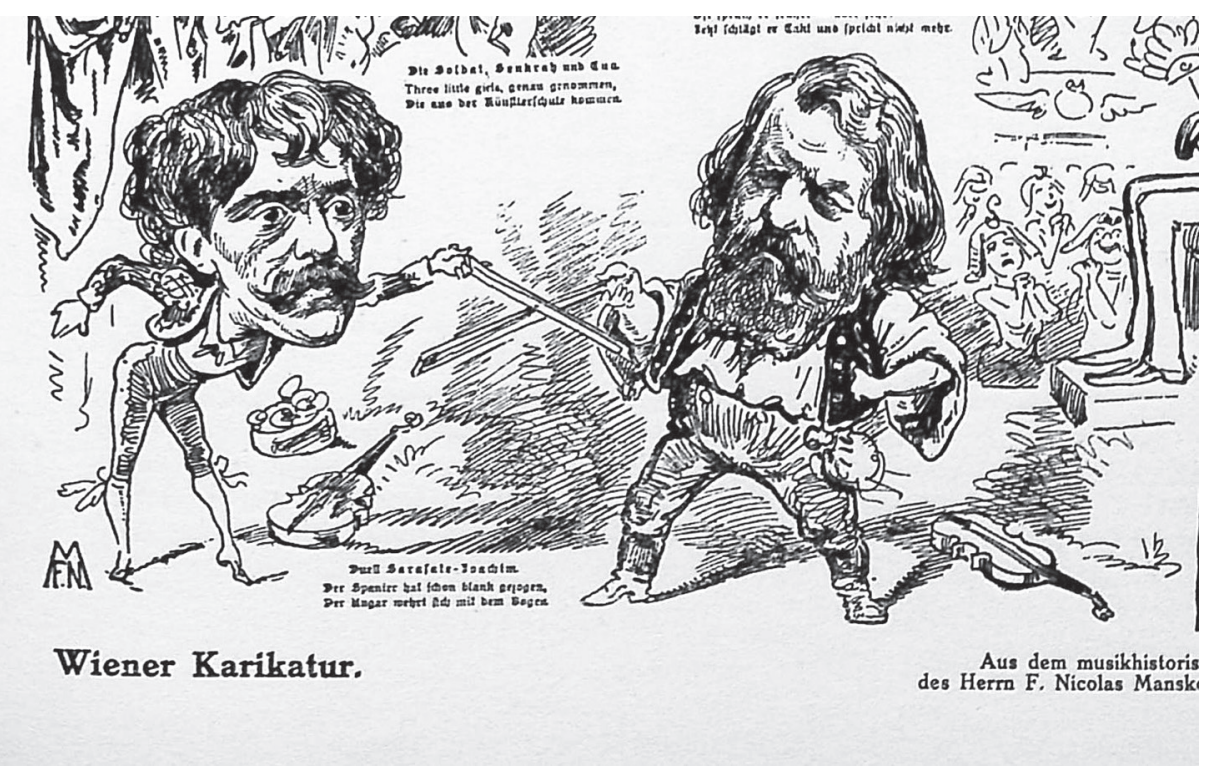

Finally, while the discussion of identity issues faced by Joachim as a musician of Hungarian Jewish heritage operating in a North German environment is expertly handled on the whole (see especially Chapter 9), the complex question of his self-proclaimed dual nationality - "as a violinist I am German, and as a composer I am Hungarian" - deserves deeper interrogation in relation to the point above. The fact that Joachim read Hungarian nationalist literature in German translation and Uhde's nifty parallel that composing in Hungarian-Gypsy style resembled working in musical translation is a key point that deserves expansion, not least because it turns out that the Hungarianness of the Hungarian Concerto is more proximate to that of Zigeunerweisen than anyone realized. Despite what he himself stated, moreover, the evidence can be read as pointing towards the potential inversion that he aspired as a violinist to be more Hungarian and as a composer to be more German.

Take the first movement cadenza in the Hungarian Concerto, for example: at the precise juncture where everyone expects maximal virtuoso fireworks, instead we discover extremely dense writing, a labour-intensive kind of technical display, passages of double-stops and triple-stops followed by passages of trills and multiple-stopped chords and so on, the sort of passagework that players of all abilities find ungrateful. Absent are improvisatory gestures and rhetorical pauses for effect, seductive harmonics and charming glissandi of the kind used by Sarasate 
invoking Hungarian-Gypsy violin-playing and even by contemporary Eastern European Roma violinists. The themes may code as "other" due to their prominent use of augmented seconds and so on, but the violin writing does not.

Ironically, as a violinist in the service of German music, Joachim buttressed and reinforced a canon he never quite joined as a composer. The imaginary museum of musical masterpieces, to amend Lydia Goehr's famous title, found a loyal performer curator in Joachim - of Beethoven's music par excellence - but ultimately included none of his own works. In the end, it seems that the conflicting binaries of nationality, of virtuoso performer vs. "priestly" performer and of performer-interpreter vs. composer remained unresolved within Joachim himself. This book goes a long way towards illuminating these tensions and marks an important step towards opening up the topic for discussion, but ultimately and perhaps unwittingly the author seems more concerned to "rescue" a "mere" performer from historical marginalization by "promoting" him to "Composer" rather than to see if an alternative performative conception of composition can emerge. All this is rich material for further unpacking from a Performance Studies perspective - to reinvoke Kerman's distinction, the canon/repertoire axis and the German/Hungarian axis revolve around each other at the core of Joachim's identity, with each axis having its own hierarchical power dynamics. A more radical conception of music creativity - one that views the performer's act and agency as primary rather than secondary - would give impetus to defusing the hierarchical master narrative of music history that Joachim himself could not escape.

Maiko Kawabata 